\title{
KARAKTERISTIK CEBAKAN EPITERMAL TIPE SULFIDASI TINGGI DI DAERAH ERELEMBANG, TOMBOLO PAO, KABUPATEN GOWA, PROVINSI SULAWESI SELATAN
}

\section{CHARACTERISTICS OF HIGH SULFIDATION EPITHERMAL DEPOSIT TYPE IN THE ERELEMBANG, TOMBOLOPAO AREA, GOWA DISTRICT, SOUTH SULAWESI PROVINCE}

\author{
Edya Putra, Bambang Nugroho Widi, dan Rudy Gunradi \\ Pusat Sumber Daya Mineral, Batubara dan Panas Bumi \\ edgeo.putra@gmail.com
}

\begin{abstract}
ABSTRAK
Mineralisasi di wilayah Erelembang, Tombolo Pao, Kabupaten Gowa, Sulawesi Selatan merupakan salah satu tipe mineralisasi yang cukup menarik di kawasan ini. Penciri utama proses mineralisasi adalah munculnya alterasi silisifikasi, argilik-argilik lanjut, dan propilitik yang membentuk suatu zona. Kehadiran mineral alterasi spesifik yang teridentifikasi meliputi alunite, halloysite, jarosite, kaolinite, dickite, dan pyrophyllite, sebagai zona argilik-argilik lanjut, dengan luas sebarannya lebih dari $2 \mathrm{~km}^{2}$, menunjukkan zona ubahan bersifat asam. Selain itu, hal lain yang menonjol adalah tekstur vuggy silica dalam zona batuan terubah karena proses pelarutan.
\end{abstract}

Hasil pengamatan pada sayatan poles diketahui mineral sulfida yang teridenfifikasi adalah pirit, tetrahidrit, kovelit, enargit, serta hydrous iron oxide, dan sedikit kalkopirit, malakit, tenantit, galena dan hematit yang terdapat secara tersebar dalam zona argilik-argilik lanjut. Korelasi mineral ubahan yang spesifik (alunite, halloysite, jarosite, kaolinite, dickite, phyrophyllite), dengan mineral bijihnya (enargit, tenantit, tetrahedrit, dan kovelit) serta vuggy silica dapat memberikan gambaran mineralisasinya tipe epitermal sulfidasi tinggi. Munculnya konsentrasi anomali merkuri di wilayah tertentu, menunjukkan bahwa model cebakannya adalah tipe epitermal sulfidasi tinggi yang terbentuk pada lingkungan yang dangkal. Penelitian ini akan memberikan informasi baru terkait dengan konsep eksplorasi yang akan diterapkan di wilayah ini.

Kata kunci: Epitermal, sulfidasi tinggi, alterasi, mineralisasi, Erelembang

\section{ABSTRACT}

Mineralization in the Erelembang region, Tombolo Pao, Gowa Regency, South Sulawesi is one of interesting mineralization in this region. The main characteristic of the mineralization is the presence of of silisic, argillic - advanced argillic, and propylitic alteration which form zones. he presence of specific alteration minerals that were identified involve alunite, halloysite, jarosite, kaolinite, dickite, and pyirophyllite as argilic-advanced argilic zone, with an area of $>2 \mathrm{~km}^{2}$, indicating an acidic alteration zones. Beside that, the most specific thing is a texture of vuggy silica found within a zone of altered rocks due to leaching procces.

The observation result on polished section are known that sulfide minerals which was identified: pyrite, tetrahidrite, kovelite, enargite, and hydrous iron oxide, and small amount of chalcopyrite, malachite, tenantite, galena and hematit found as dissemination within argilicadvanced argilic zone. Correlation between specific alteration minerals (alunite, halloysite, jarosite, kaolinite, dickite, phirophyllite), and ore mineral (enargite, tenantite, tetrahedrite, and kovelite), and vuggy silica can give ilustration that mineralization can occured in a high sulfidation. The raise of merkuri anomaly in certain region, it seem indicate that the deposit 


\section{MAKALAH ILMIAH}

model of this area is a high sulfidation epithermal type, formed in the shallow environments. This research will give a new information related with exploration concept that will be applied in this area.

Keywords: Epithermal, high sulfidation, alteration, mineralization, Erelembang

\section{PENDAHULUAN}

Daerah penelitian secara administratif terletak di Desa Erelembang, Kecamatan Tombolopao, Kabupaten Gowa, Provinsi Sulawesi Selatan (Gambar 1). Secara geografis dibatasi oleh koordinat $119^{\circ} 51^{\prime}$ $33.92^{\prime \prime}-119^{\circ} 55^{\prime} 4.08^{\prime \prime}$ Bujur Timur dan $5^{\circ}$ 7' 2.23" - 5० 11' 41.71" Lintang Selatan. Secara geologi daerah tersebut merupakan suatu unit stratigrafi-tektonik atau lithotektonik pada Busur Vulkano-Plutonik Sulawesi Bagian Utara sampai Sulawesi Bagian Barat. Jalur tersebut (Sulawesi bagian Utara - Sulawesi bagian Barat) banyak sekali ditemukan cebakan mineral dengan berbagai tipe cebakan. diantaranya porfiri, skarn, epitermal sulfidasi rendah (LS) dan sulfida tinggi (HS), VMS dan sebagainya (Leeuwen and Pieters, 2011).

Daerah Erelembang memiliki ciri mineralisasi berbeda dengan daerah lain di sekitarnya, seperti di daerah Talatala Sungai Balang Makorret yang umumnya berupa tipe urat dengan ketebalan $5 \mathrm{~cm}$ s.d. $50 \mathrm{~cm}$ dan berarah relatif Barat-Timur, yang berada dalam batuan vulkanik terubah kuat dengan kumpulan mineral alterasi hidrotermal, seperti serisit, felspar (kaolin), kuarsa, pirit dan sedikit epidot (Zulkifli. MD, 2002).

Sedangkan daerah Erelembang, pemineralan yang terbentuk bukan berupa tipe urat, namun tersebar (disseminated) dalam zona alterasi argilik-argilik lanjut, dengan kumpulan mineral alterasi berupa: alunite, halloysite, jarosite, kaolinite, dickite, pyrophyllite. Kehadiran mineral ubahan alunite di daerah Erelembang ini menjadi pembeda di antara kedua daerah mineralisasi tersebut, meskipun keduanya berkembang di dalam batuan vulkanik pada formasi batuan yang sama. Hal tersebut menjadi alasan dilakukannya penelitian di wilayah Erelembang ini dengan tujuan untuk mengetahui karakteristik cebakannya.

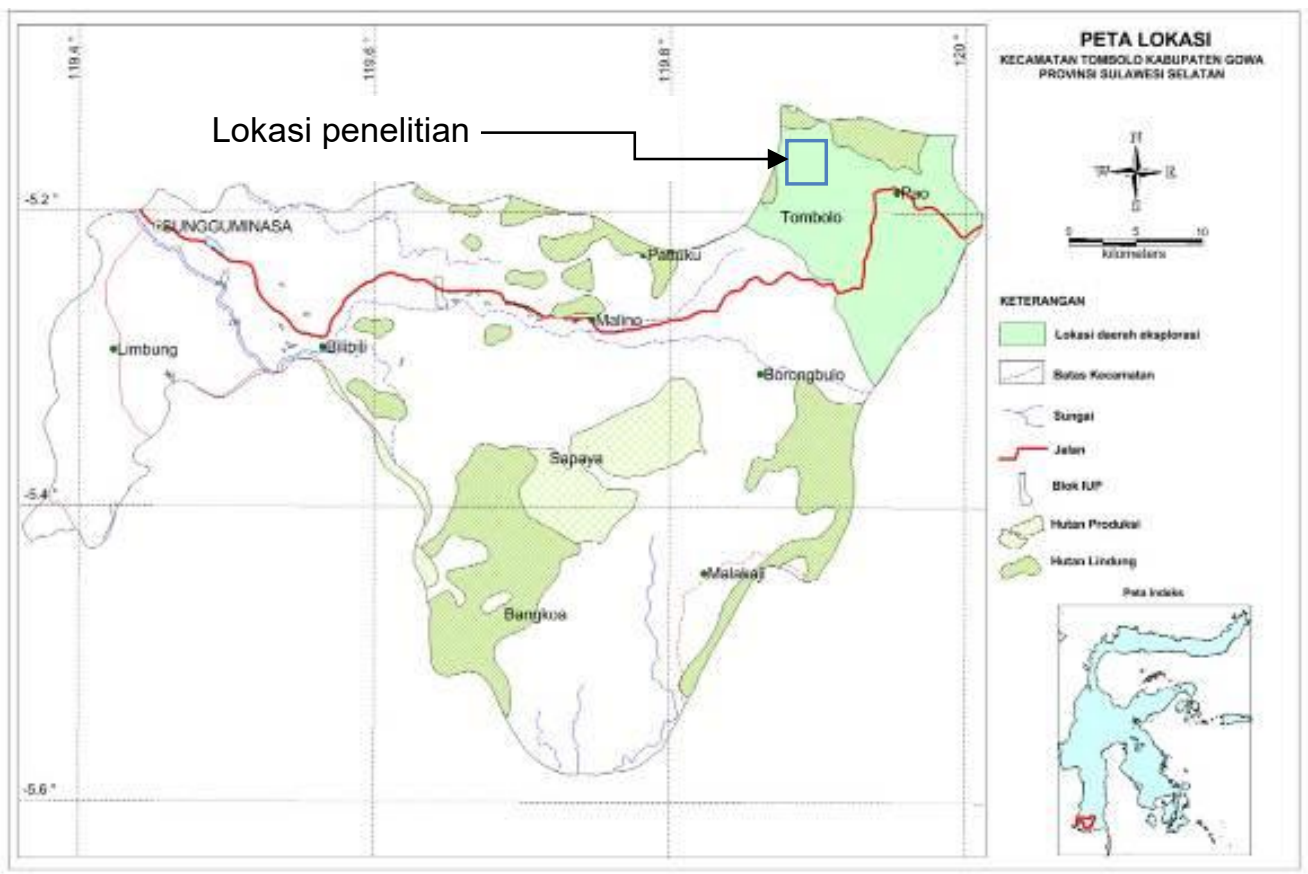

Gambar 1. Peta lokasi daerah penelitian 


\section{METODOLOGI}

Kegiatan penelitian dilakukan dengan cara pengamatan dan pemetaan geologi pada lintasan sungai, punggungan dan jalan di sekitar daerah terpilih. Maksudnya untuk mengamati perubahan satuan batuan, jenis batuan, alterasi dan mineralisasi serta gejala-gejala geologi lainnya. Pengumpulan data dan informasi primer yang dilakukan berupa:

- Pemetaan geologi dan alterasi skala 1:25.000.

- Pemercontoan tanah (ridge and spur) dan batuan termineralisasi (rock chip, float chip, channeling).

Uji Laboratorium yang dilakukan di Pusat Sumber Daya Mineral Batubara dan Panas Bumi (PSDMBP) meliputi analisis kimia dengan metode AAS yang terdiri dari conto tanah dan batuan, analisis petrografi, mineragrafi, dan analisis mineral dengan infrared analyzer (PIMA). Pengolahan hasil analisis conto tanah dengan statistik deskripsi sederhana, serta plotting data pada peta dasar ber skala $1: 5000$.

\section{TEKTONIK DAN GEOLOGI REGIONAL}

Telah banyak penelitian terkait latar belakang tektonik Pulau Sulawesi diantaranya; Kadarusman et al. 2004; Van Leuwen and Pieters 2011; Monnier, C., Parkinson 1998). Secara umum pulau Sulawesi dapat dibagi menjadi empat provinsi geologi dan metalogeni, yaitu: (1) Sulawesi Bagian Utara, (2) Sulawesi Bagian Barat, (3) Sulawesi Bagian Timur, (4) Banggai Sula (Gambar 2). Provinsi Bagian Utara dan Bagian Barat Sulawesi dianggap sebagai sebuah unit stratigrafitektonik atau lithotektonik yang disebut Busur Vulkano-Plutonik, dimana lokasi penelitian terdapat.

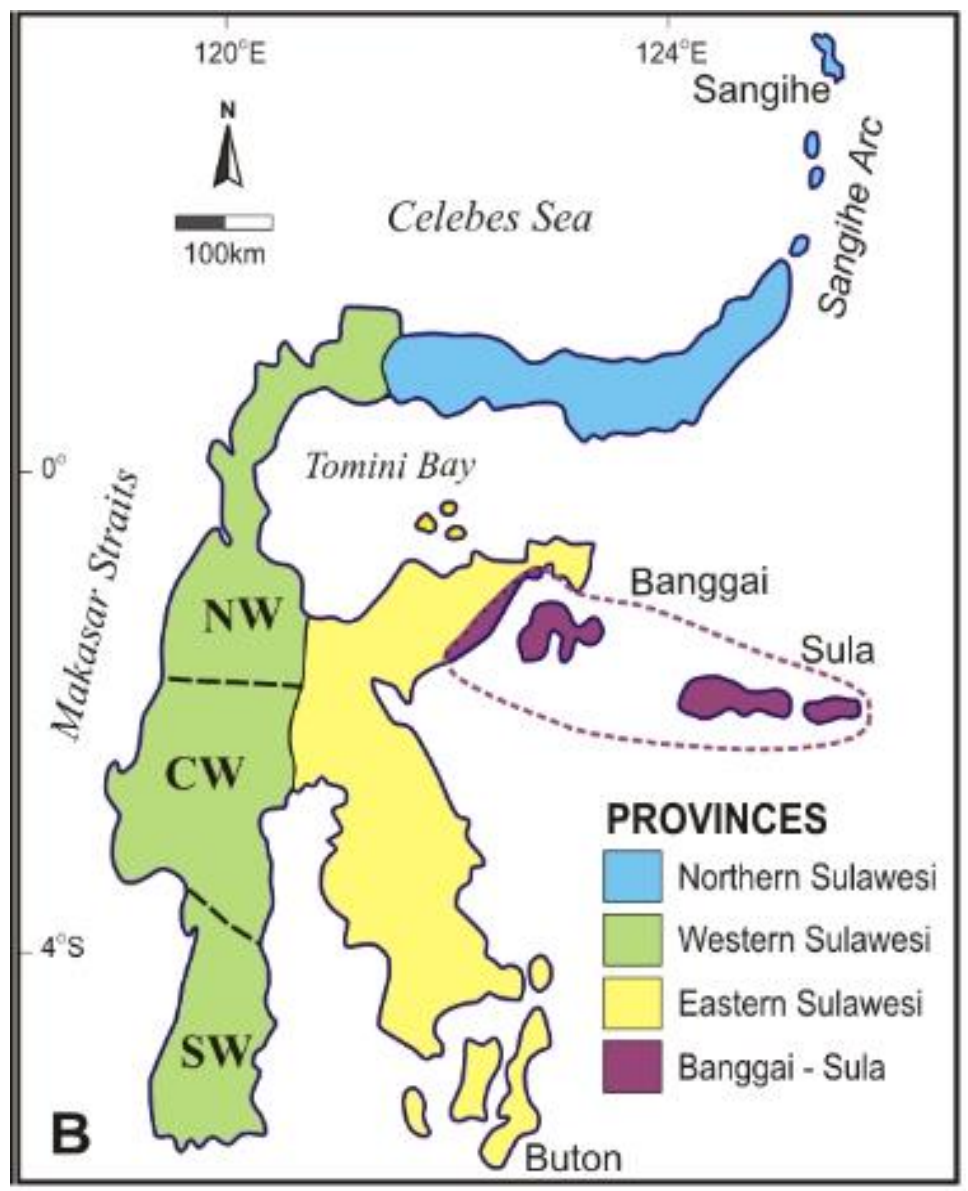

Gambar 2. Pulau Sulawesi terbagi menjadi empat provinsi geologi dan metalogeni (Leeuwen and Pieters, 2011) 


\section{GEOLOGI REGIONAL}

\section{Stratigrafi}

Merujuk pada Peta Geologi Lembar Ujung Pandang, Benteng, dan Sinjai, Sulawesi (Rab Sukamto dan Sam Supriatna, 1982) (Gambar 3), stratigrafi daerah penyelidikan ditempati oleh satuan batuan tertua Formasi Tonasa (Temt) yang terdiri dari batugamping pejal dan berlapis, koral, bioklastik, kalkarenit dengan sisipan napal, batugamping pasiran, dengan umur Eosen sampai Miosen Tengah. Di atas terdapat Formasi Camba (Tmc) tersusun dari batuan sedimen laut berselingan dengan batuan gunungapi, batupasir tufaan berselingan dengan tufa, batupasir dan batu lempung bersisipan napal, batugamping, konglomerat, breksi gunungapi dan batubara. Formasi Camba (Tmc) menjemari dengan batuan gunungapi Formasi Camba (Tmcv), terdiri dari breksi gunungapi, lava, konglomerat dan tufa berbutir halus hingga lapili berumur Miosen Tengah sampai Pliosen.

Batuan Gunungapi Baturappe - Cindako (Tpbv) terbentuk secara setempat, terdiri dari lava dan breksi bersusunan basal dengan sisipan sedikit tufa dan konglomerat, umumnya didominasi oleh lava (Tpbl) berumur Pliosen Akhir. Satuan batuan gunungapi termuda adalah Batuan Gunungapi Lompobatang (QIv), terdiri dari aglomerat, lava, breksi, endapan lahar dan tufa berumur Plistosen. Sedimen termuda berupa endapan aluvial dan pantai (Qac), berumur Holosen.

Batuan terobosan diorit (d) berupa stok dan retas atau sill, menerobos Formasi Tonasa (Temt), Formasi Camba (Tmcv) dan batuan Gunungapi Baturappe - Cindako (Tpbv) menyebabkan batuan di sekitarnya terubah kuat, berumur Miosen Akhir (JD. Obradovich, 1974). Batuan terobosan andesit/trakhit $(\mathrm{a} / \mathrm{b})$ berupa retas dan stock menerobos batuan gamping Formasi
Camba (Tmcv) dan Batuan Gunungapi Baturappe - Cindako (Tpbv). Batuan terobosan basal (b) berupa retas, sill dan stok, di antaranya mempunyai tekstur gabro. Terobosan basal di Jenebarang merupakan kelompok retas berpola radier yang memusat ke Baturappe dan Cindako, sedangkan yang di sebelah utara Jeneponto berupa stock berumur Miosen Akhir sampai Pliosen Akhir.

\section{Struktur Geologi}

Struktur geologi daerah ini berupa sesar dan kekar. Sesar umumnya berarah Utara - Selatan sampai Barat Laut - Tenggara, berupa sesar geser dan sesar normal dan sesar naik. Kekar secara umum berarah Barat Laut - Tenggara sampai Timur Laut Barat Daya dengan intensitas rendah, terutama dijumpai pada batuan terobosan dan batuan Gunungapi Baturappe Cindako.

\section{GEOLOGI DAERAH PENELITIAN}

Litologi daerah Erelembang dibagi menjadi tiga satuan batuan dari tua ke muda sebagai berikut: Satuan Lava Andesit, Satuan Tufa, dan Satuan Lava Andesit Muda. (Gambar 4).

Satuan Lava Andesit ini merupakan satuan paling luas sebarannya, sebagian besar sudah terubah, yang didominasi oleh lava andesit afanitik, setempat porfiritik, breksi andesit, dan retas andesit memotong lava andesit, dan setempat dasit di bagian hulu Sungai Karo-karo. Lava Andesit afanitik mumpunyai ukuran butir halus, fenokris plagioklas agak jarang, masif, keras, berwarna abu-abu gelap, dan bersifat basaltik. Sebagian besar satuan ini sudah mengalami ubahan, hampir di sepanjang Sungai Erelembang, dan di sebagian besar Sungai Lantikia, dan Sungai Karo-karo. Satuan ini diduga bagian dari Formasi Batuan Gunungapi Baturappe-Cindako (Tpbv) berumur Pliosen Akhir. 


\section{MAKALAH ILMIAH}

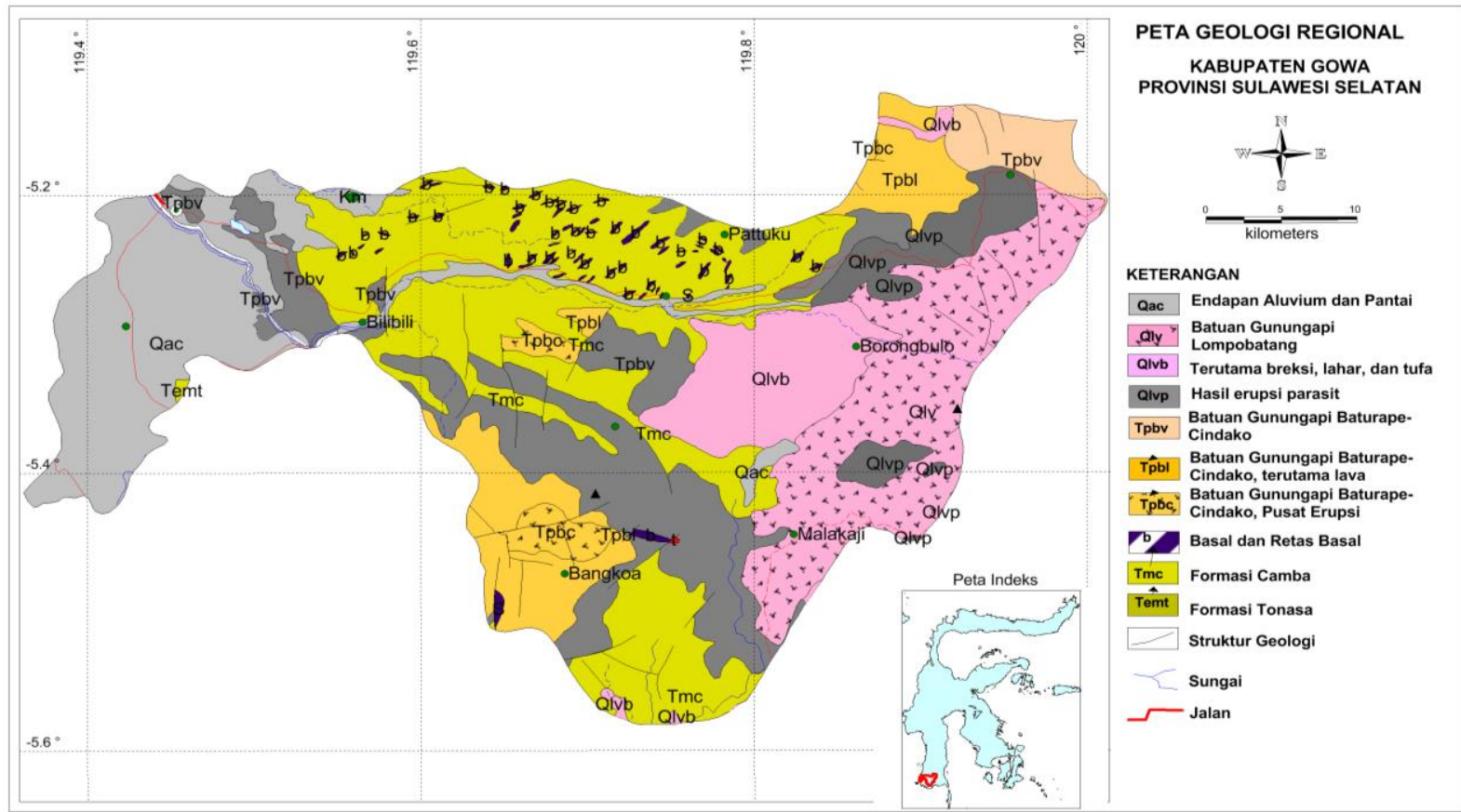

Gambar 3. Peta geologi regional Kabupaten Gowa, Provinsi Sulawesi Selatan (Rab Sukamto dan Sam Supriatna, 1982)

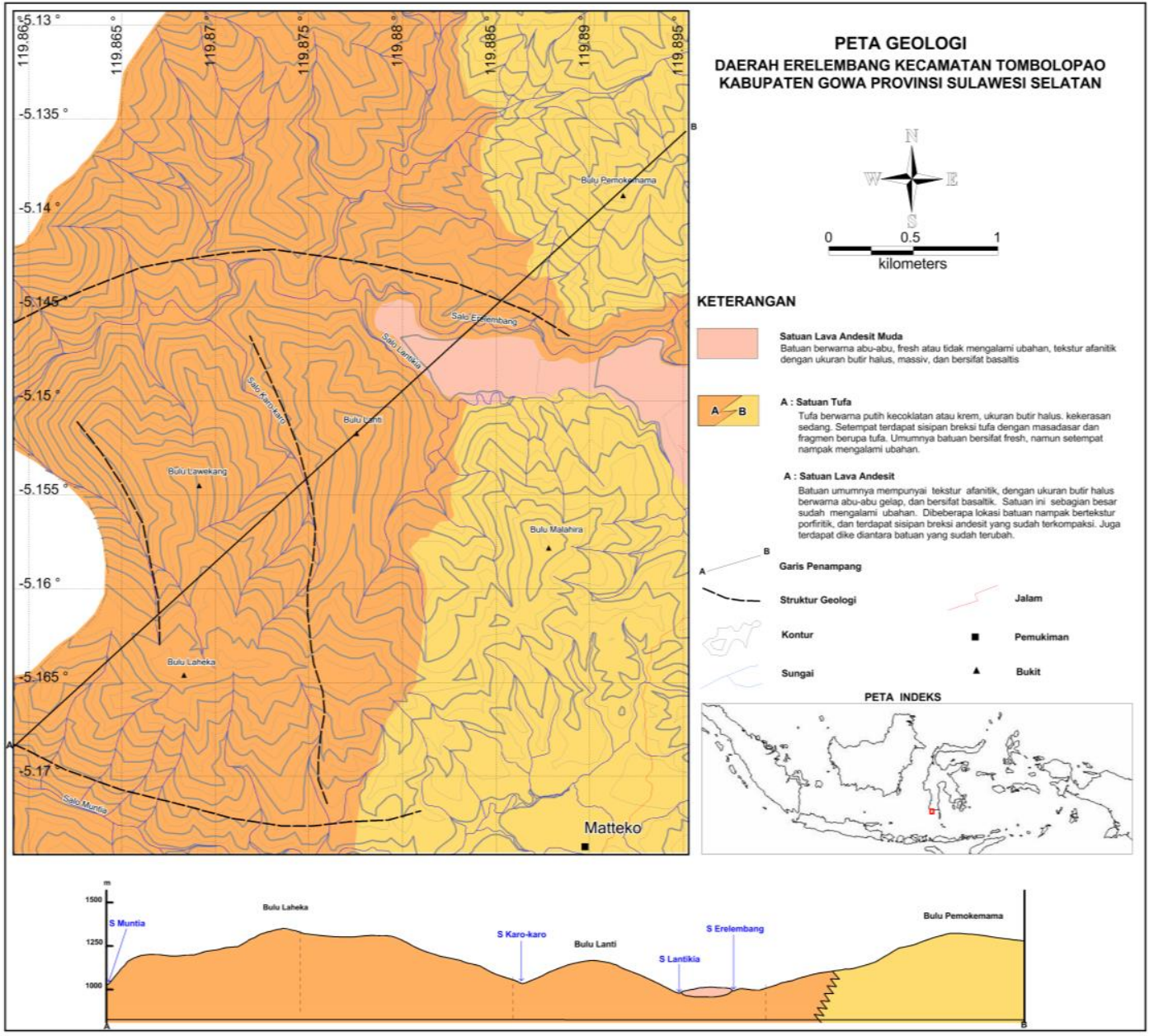

Gambar 4. Peta Geologi Daerah Erelembang, Kabupaten Gowa, Provinsi Sulawesi Selatan 
Satuan Tufa menjemari dengan Satuan Lava Andesit. Selain tufa, juga nampak breksi tufa sebagai sisipan dalam satuan tufa tersebut. Selain itu setempat juga nampak tufa lapilli dengan ukuran butir sedang. Secara megaskopis diidentifikasi tufa berwarna putih kecoklatan atau krem, ukuran butir halus, kekerasan sedang, terdiri dari material debu vulkanik, dan setempat sisipan breksi tufa dengan masadasar dan fragmen berupa tufa, umumnya bersifat segar, setempat nampak mengalami ubahan. Satuan ini diduga merupakan bagian dari Formasi Batuan Gunungapi Baturappe - Cindako (Tpbv) yang berumur Pliosen Akhir.

Satuan Lava Andesit merupakan satuan batuan paling muda. Secara megaskopis berwarna abu-abu, bertekstur afanitik dengan ukuran butir halus, masif, bersifat basaltis, dan batuan segar atau tidak mengalami ubahan. Satuan ini diduga termasuk dalam Formasi batuan Gunungapi Lompobatang (QIv), yang berumur Plistosen.

Struktur geologi daerah ini berupa kekar dan sesar. Petunjuk struktur geologi yang teramati pada singkapan berupa kekarkekar diantaranya columnar joint, dan kelurusan sungai terbentuk sepanjang sesar relatif berarah Utara - Selatan sampai Barat Laut - Tenggara, dan juga relatif berarah Barat - Timur.

\section{Alterasi dan Mineralisasi}

Zona alterasi juga dijumpai di daerah Erelembang, terdiri dari zona propilit, argilik-argilik lanjut, dan silisifikasi. Zona propilit terdapat di bagian luar atau pinggir zona alterasi argilik pada bagian timur, utara serta bagian selatan daerah penelitian. Zona alterasi argilik paling luas, penyebarannya lebih dari $2 \mathrm{~km}^{2}$ yang secara megaskopis berwarna putih keabuan hingga abu-abu cerah, sebagian besar mengandung pirit halus dan menyebar dalam batuan. Sebagian besar batuannya agak keras, di bagian luar umumnya teroksidasi dengan warna kecoklatan. alterasi silisifikasi cukup luas nampak di daerah sekitar Bulu (bukit) Laheka dan kadangkala setempat dalam zona alterasi argilik.

Mineralisasi dominan teramati langsung di lapangan terdiri dari pirit, malakit dan sedikit kalkopirit, yang umumnya tersebar luas (disseminated) dalam alterasi argilik.

\section{HASIL DAN ANALISIS}

Analisis laboratorium kimia terhadap 76 conto batuan terubah dan termineralisasi, menunjukkan kadar yang tidak signifikan. Unsur Au berkisar: 1 - 35 ppb, Ag: 0,1 - 2,9 ppm, Cu: 2 - 136 ppm, Pb: 1 - 317 ppm, Zn: 1 - 220 ppm.

Hasil analisis kimia terhadap 31 conto tanah, menunjukkan kadar unsur $\mathrm{Au}$ berkisar: 1 - 24 ppb, Ag: 1 - 2,2 ppm, Cu: 10 - 120 ppm, Pb: 32 - 90 ppm, Zn: 7 - 189 ppm, As: 3 - 26 ppm, Sb: 3 - 10 ppm, dan $\mathrm{Hg}: 14$ - $163 \mathrm{ppb}$. Meski menunjukkan kadar yang rendah, dari permukaan namun dilihat dari pola sebaran unsurnya, $(\mathrm{Au}, \mathrm{Hg}$, dan $\mathrm{Cu}$ ) cukup menarik, serta ditunjang dengan data alterasi. Dilihat dari peta sebaran, anomali unsur Au nampak berada dekat puncak Bulu Laheka bagian Timur dan punggungan Selatan Bulu Lawekang hingga percabangan Bulu Laheka (Gambar 5).

Peta sebaran anomali $\mathrm{Hg}$ (Gambar 6), menunjukkan anomali hampir terdapat di sepanjang punggungan Bulu Lawekang bagian Selatan, sangat kontras dibanding dengan daerah lainnya. Diduga kuat bahwa anomali $\mathrm{Hg}$ memberikan korelasi dengan anomali Au yang juga dominan di sepanjang punggungan Bulu Lawekang di bagian Selatan. (Gambar 5 dan Gambar 6). 


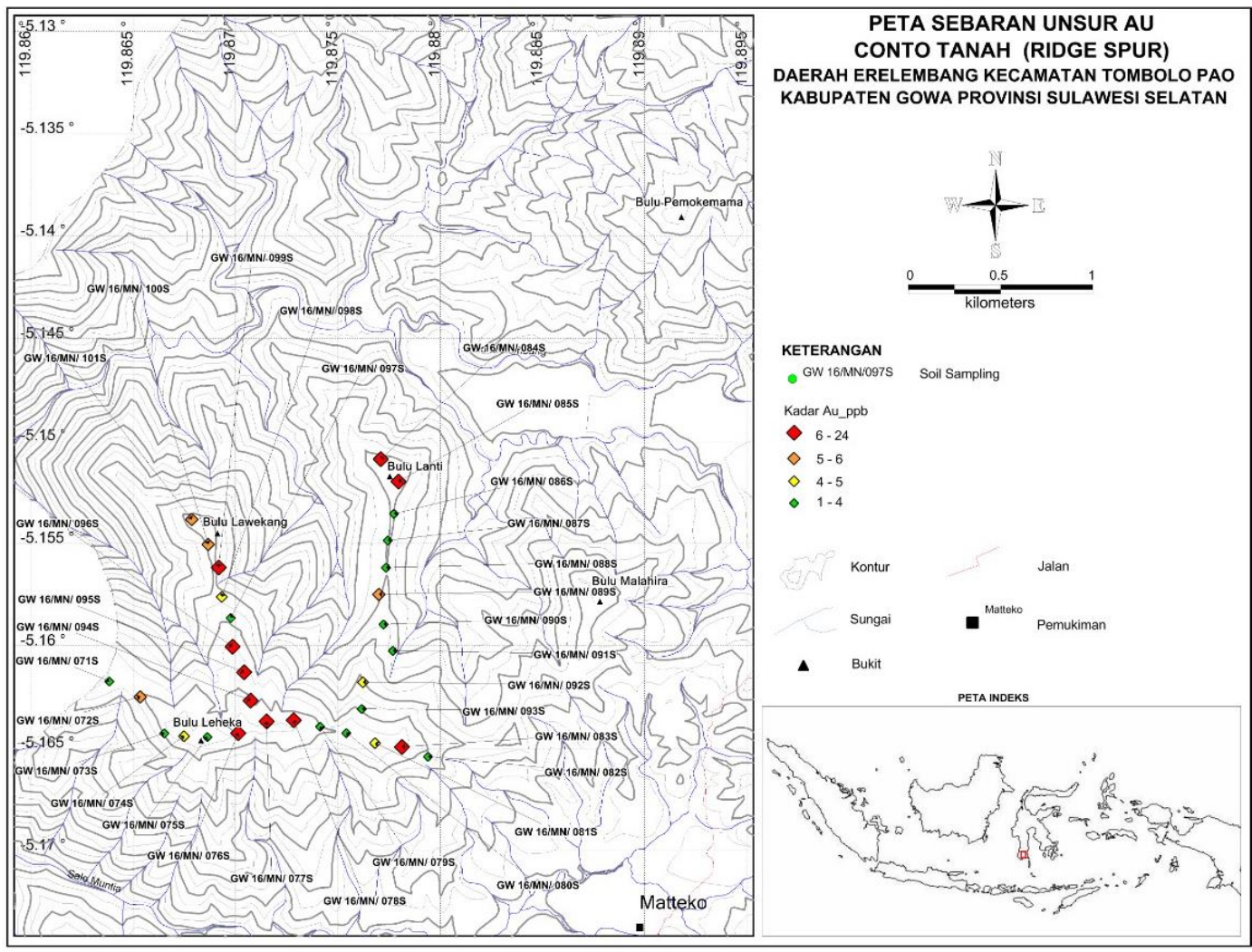

Gambar 5. Peta sebaran unsur Au (ppb) dari conto tanah

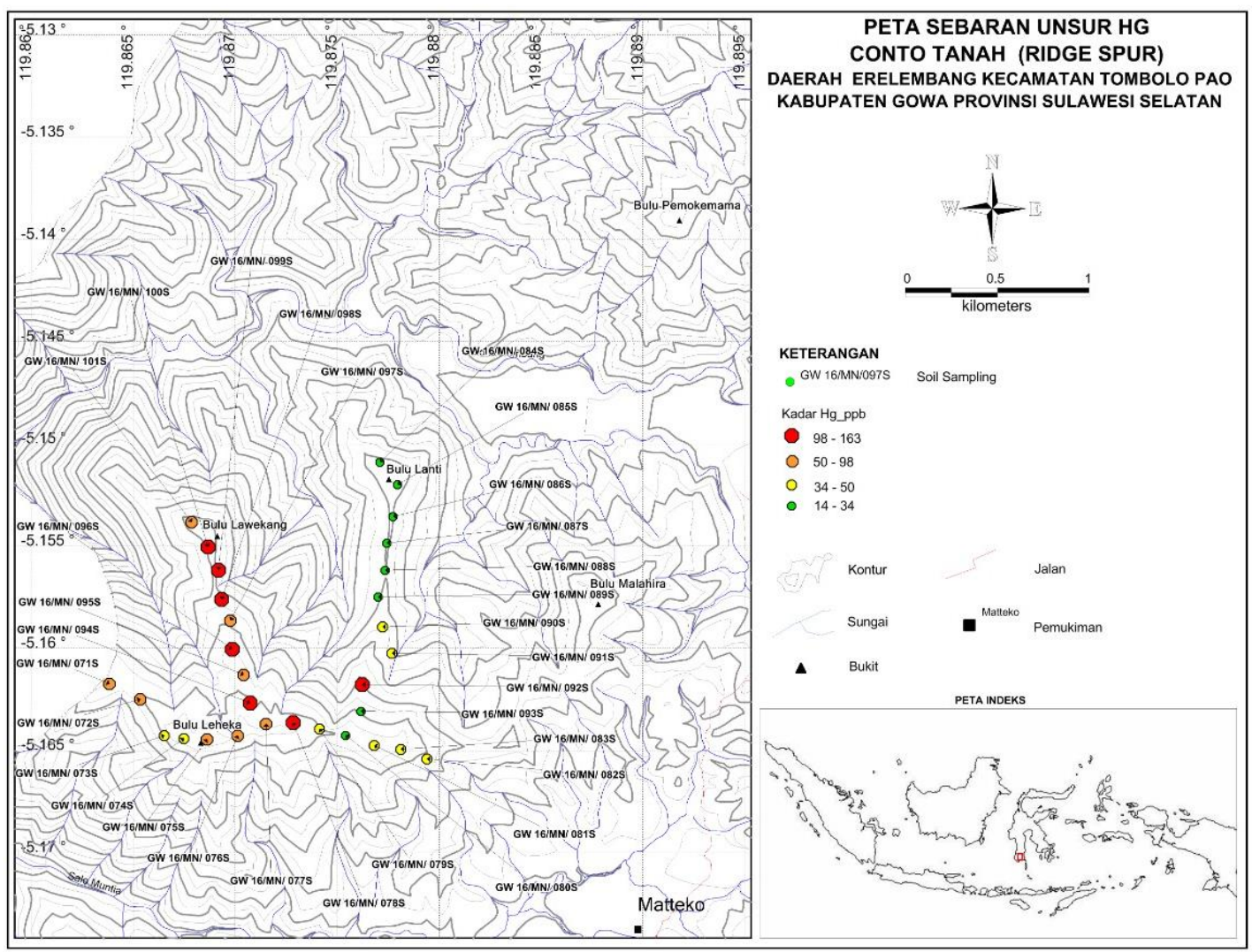

Gambar 6. Peta sebaran unsur $\mathrm{Hg}(\mathrm{ppb})$ dari conto tanah 
Pada peta sebaran unsur (Gambar 7), unsur $\mathrm{Cu}$ memperlihatkan pola sebaran anomali yang terpola. Sebaran anomali tersebut, hampir di sepanjang punggungan Bulu Lanti hingga percabangan dengan punggungan Bulu Leheka.

Analisis mineragrafi terhadap 11 conto batuan termineralisasi, mineral logam yang teridentifikasi didominasi oleh pirit, diikuti dengan sejumlah variasi mineral: tetrahidrit (tet), kovelit (cv) enargit (Eng), serta hydrous iron oxide, dan sedikit kalkopirit (Cpy), malakit (Mal), tenantit (tn), galena (Gn) dan hematit (hm).

Mineral ubahan (Gambar 8) diidentifikasi dengan metode PIMA sebanyak 17 contoh yang hasilnya menunjukkan kumpulan mineral ubahan zona alterasi argilik (kaolinite, illte, montmorilonite), zona alterasi argilik lanjut (alunite, pyrophyllite, halloysite), dan zona propilit (illite-chlorite) (Gambar 9).

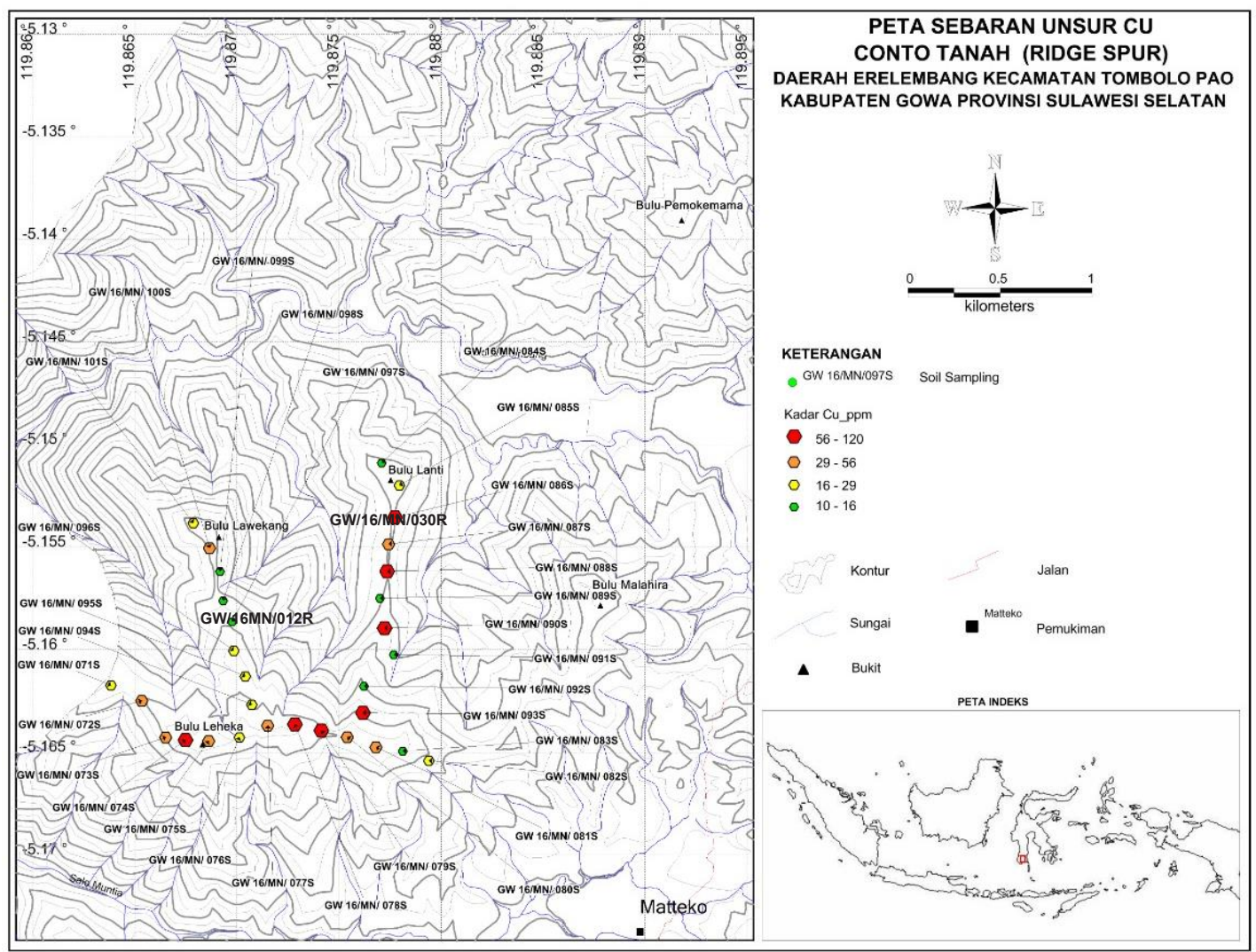

Gambar 7. Peta sebaran unsur $\mathrm{Cu}(\mathrm{ppm})$ dari conto tanah
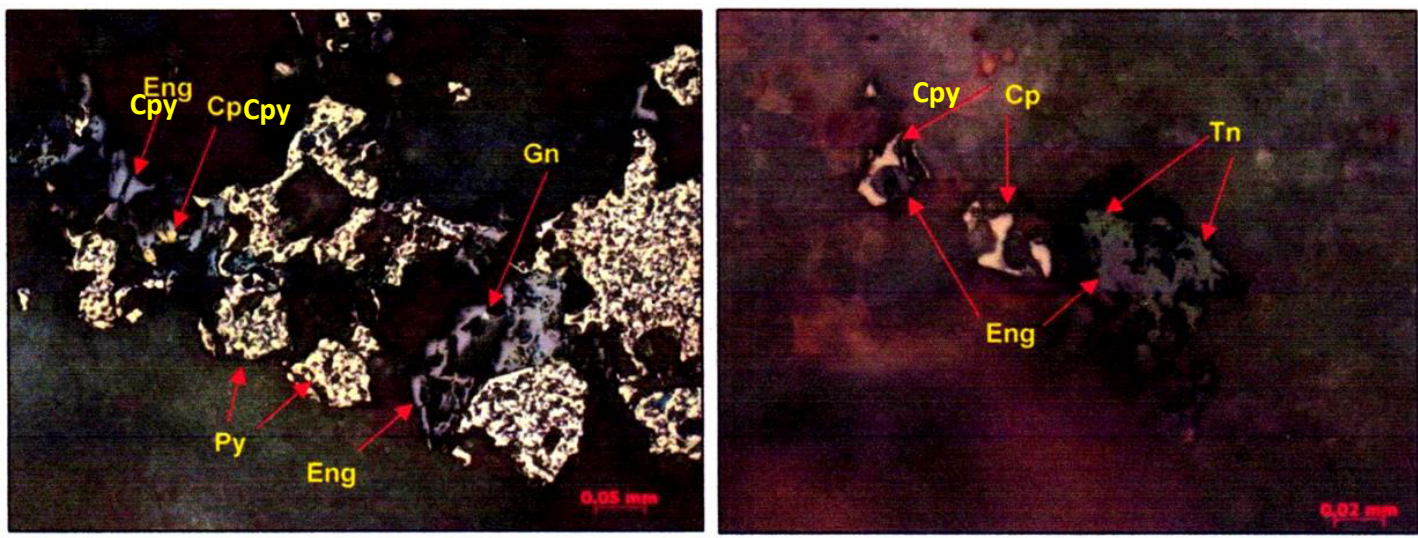

Gambar 8. Fotomikrograf sayatan poles pada conto GW/16/MN/030R 


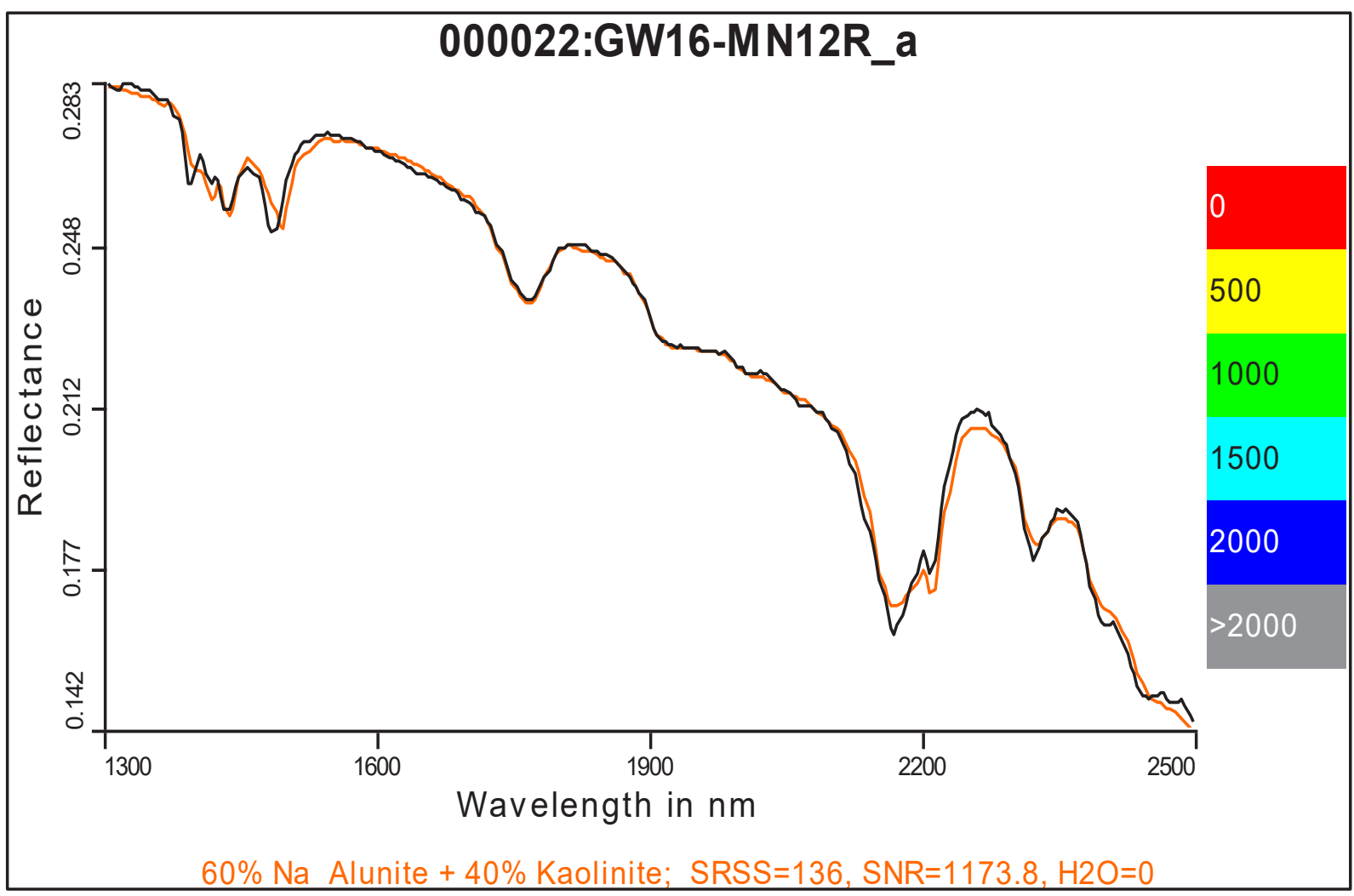

Gambar 9. Salah satu hasil Analisis dengan PIMA

pada conto GW/16MN/012R menunjukkan Alunit dan kaolinit

\section{Karakteristik Mineralisasi}

Luasnya sebaran atau zona alterasi daerah Erelembang lebih dari $2 \mathrm{~km}^{2}$, diduga kontrol litologi lebih dominan, selain kontrol struktural yang merupakan faktor menonjol berarah relatif utara - selatan. Hal tersebut dapat dilihat dari sebaran alterasi (Gambar 17). Hasil pengamatan di lapangan yang didukung analisis dengan PIMA, menunjukkan zona alterasi daerah penyelidikan terdiri dari; zona silisifikasi (massive silica \& vuggy silica), zona argilikargilik lanjut, dan zona propilit.

Silisifikasi sebarannya terbatas hanya menempati wilayah tertentu, masih termasuk dalam wilayah ubahan argilik. (Gambar 17) Sebaran zona silisifikasi terdapat di sekitar Bulu Laheka, atau bagian selatan punggungan Bulu Lawekang. Selain berupa singkapan, juga tampak boulder tersilisifikasi, umumnya berwarna abu-abu, breksia, setempat vuggy, sulfida pirit sangat jarang, sebagian nampak teramati berupa boulder massive silica dan vuggy silica.

Zona argilik di daerah Erelembang tersebar cukup luas $\left(>2 \mathrm{~km}^{2}\right)$. Zona alterasi ini berkembang cukup baik, terutama di daerah bagian tengah sampai bagian barat wilayah penyelidikan, tersebar dihampir sepanjang Sungai Lantikia, dan Sungai Karo-karo (Gambar 11). Secara megaskopis alterasi argilik berwarna putih keabuan hingga abu-abu cerah, sebagian besar mengandung pirit halus dan tersebar dalam batuan. Pada bagian luar batuan mengalami oksidasi (coklat keputihan) karena faktor pelapukan. Di beberapa lokasi dijumpai ada singkapan argilik-argilik lanjut terutama di tebing-tebing sungai (Gambar 11). 


\section{MAKALAH ILMIAH}

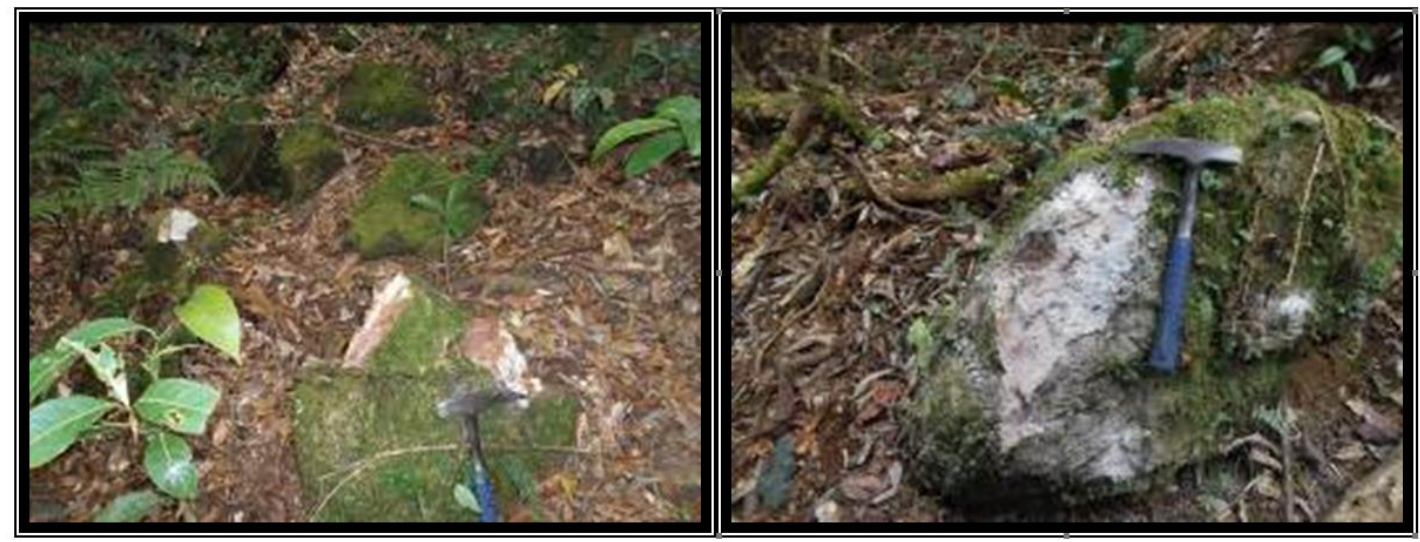

Gambar 10. Sebaran boulder silisifikasi (massive silica \& vuggy silica) di lereng pungungan Bulu Lawekang

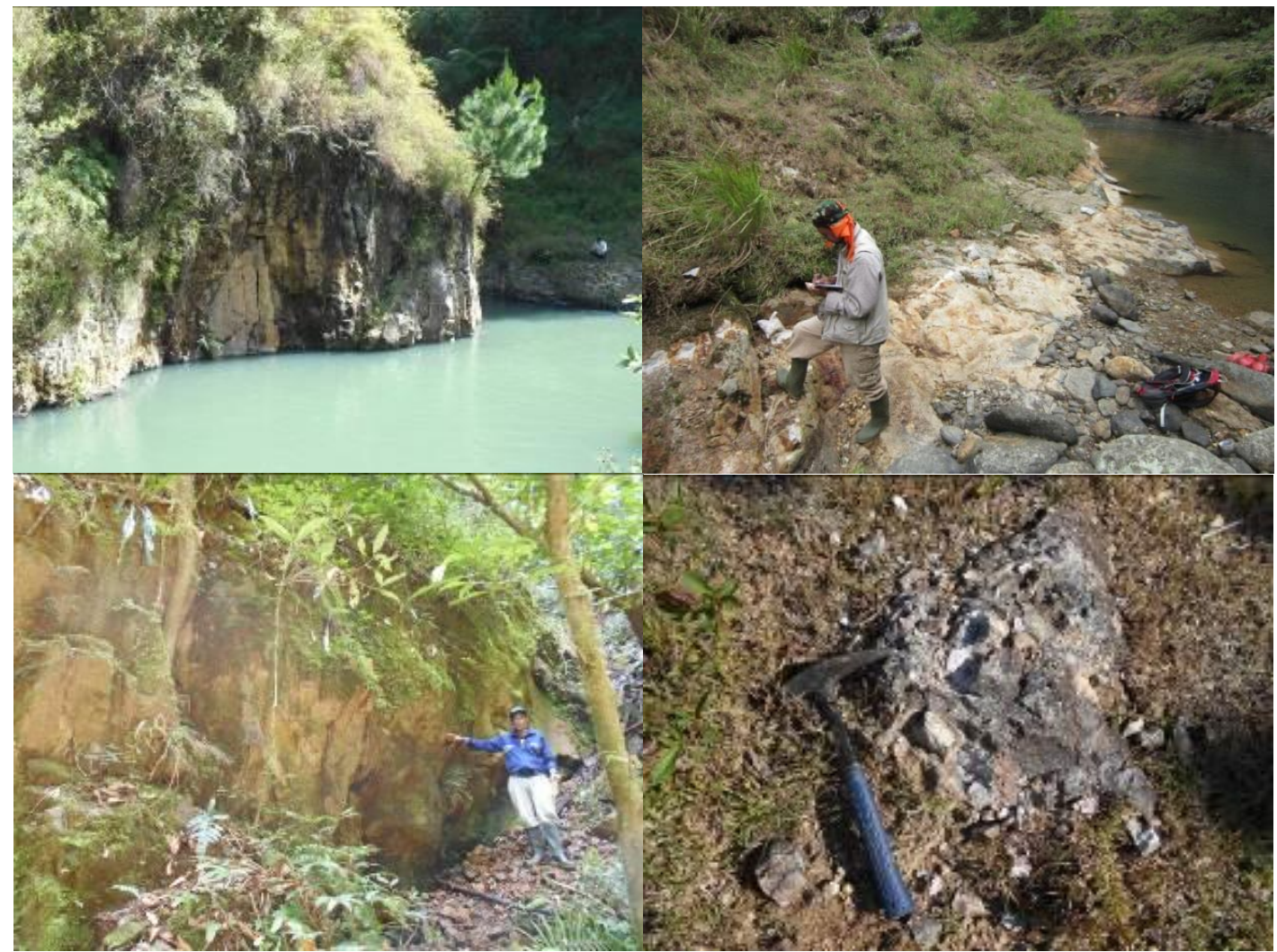

Gambar 11. Zona Argilik di Sungai Erelembang, Sungai Karo-Karo, dan pungungan Bulu Lanti

Berdasarkan analisis dengan PIMA, mineral ubahan teridentifikasi dari zona alterasi argilik-argilik lanjut. Zona argilik dicirikan dengan hadirnya mineral-mineral ubahan kaolinite, illite, montmorilonite, dan sementara zona alterasi argilik lanjut dicirikan oleh alunite, pyrophyllite, halloysite, dickite (Pirajno, Franco, 2016). Berdasarkan identifikasi tersebut maka hadirnya kelompok alunite, halloysite, jarosite, kaolinite, dickite, dan pyrophyllite, dimasukkan ke dalam zona alterasi pada batuan asam (Hedenquist, 1996) dan (Arribas, 1995).

Zona propilit memiliki penyebaran di bagian luar / pinggir dari zona argilik, yang tersebar di bagian timur, utara dan selatan daerah penyelidikan. Alterasi propilit ini ditandai dengan hadirnya mineral klorit, sebagian besar mengandung pirit, dan berwarna kehijauan, salah satunya dijumpai di anak 
sungai atau cabang timur Sungai Lantikia (Gambar 12). Identifikasi mineral ubahan dari analisis dengan PIMA menunjukkan kehadiran mineral illite - chlorite dalam zona propilit ini.

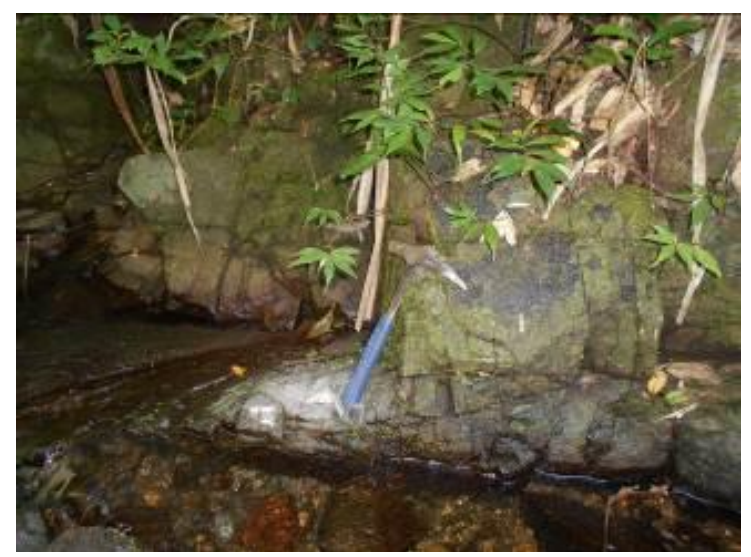

Gambar 12. Zona Propilit pada batuan lava andesit di Sungai Rakjing anak sungai Mateko (bagian selatan daerah penyelidikkan)

Alterasi mineral di daerah Erelembang cukup menarik, dengan keberadaan zona argilik-argilik lanjutnya yang memiliki sebaran cukup luas. Mineralisasi awal yang terbentuk adalah pirit secara tersebar. malakit dan kalkopirit hadir dalam bentuk spotted dengan tekstur staining (Gambar.13A), sedangkan kalkopirit jarang dijumpai (Gambar 13B). Jenis mineral sulfida tersebut terdapat dalam zona argilik-argilik lanjut Selain keterdapatan logam dasar terutama $\mathrm{Cu}$, indikasi kemungkinan adanya logam mulia (Au) dapat dilihat salah satu datanya yaitu ditemukannya vuggy silica di beberapa lokasi, terutama di bagian selatan jalur punggungan Bulu Laheka. Meskipun hasil analisis laboratorium pada batuan menunjukkan kadar Au yang rendah (1 ppb s.d. $35 \mathrm{ppb}$ ), namun pola alterasi menunjukkan kecenderungan pola yang baik. Beberapa bukti lapangan yang cukup kuat menunjukkan bahwa mineralisasi di wilayah ini terkait dengan tipe sulfida tinggi yaitu adanya Vuggy silica yang dijumpai di bagian selatan Bulu Laheka tepatnya di lokasi GW/16MN/45 (Gambar14).

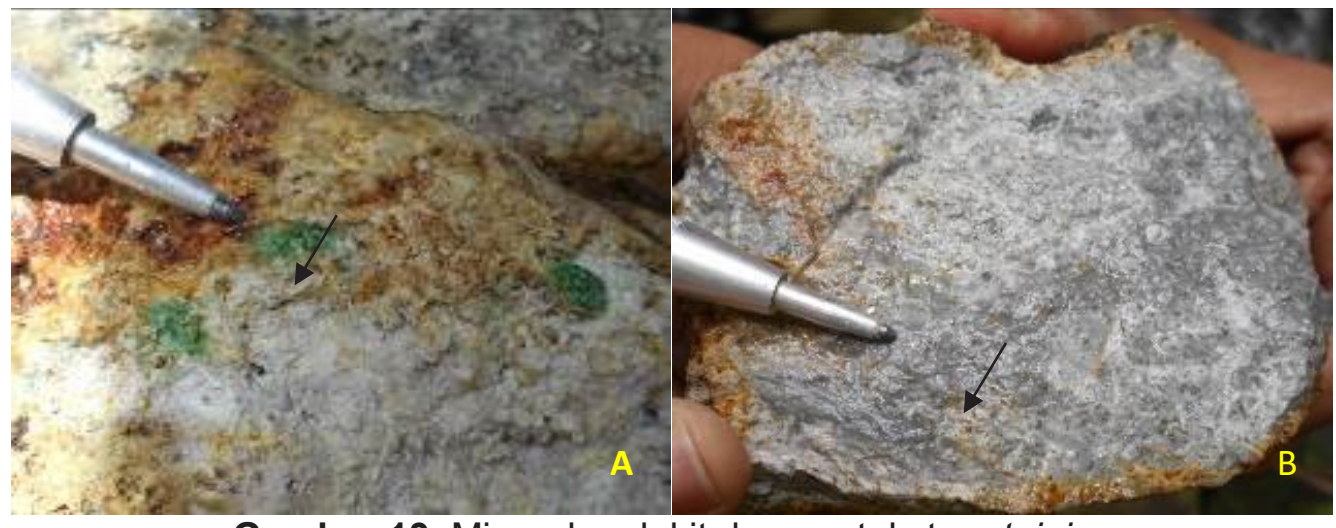

Gambar 13. Mineral malakit dengan tekstur staining lokasi Sungai Erelembang (A), kalkopirit spotted, Lokasi Sungai Karo-Karo (B)

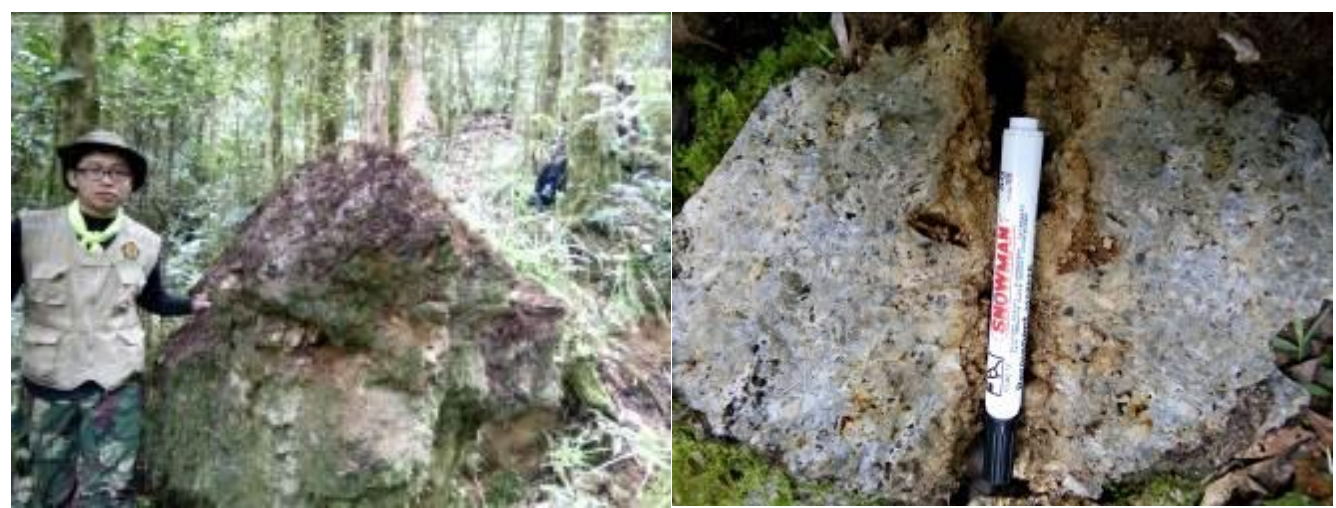

Gambar 14. Vuggy Silica di bagian selatan Bulu Laheka (GW/16MN/045R) 


\section{MAKALAH ILMIAH}

Bongkahan vuggy silica, diameter $0,8 \mathrm{~m}$ menyudut yang ditemukan di sungai Karokaro diduga merupakan longsoran dari lereng bukit (gambar 15).

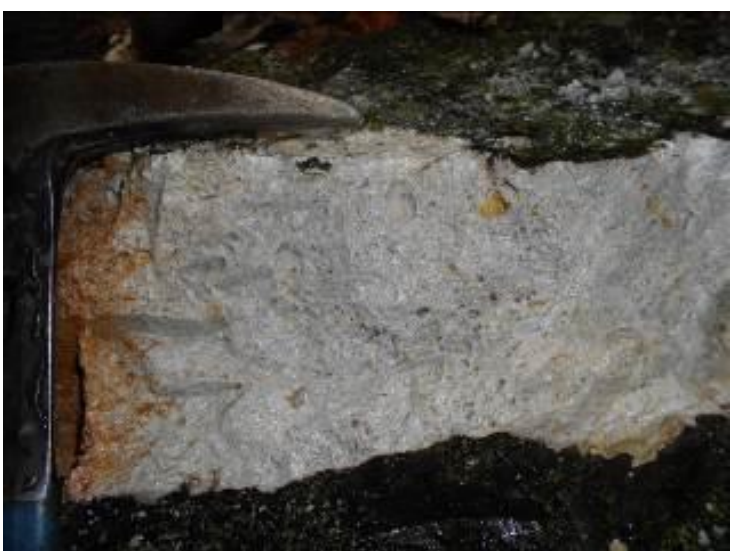

Gambar 15. Vuggy silica di Sungai Karokaro

Boulder silika yang didapati di salah satu lereng Bulu Lawekang (massive silica- vuggy) silika berwarna abu-abu hingga putih kemerahan (Gambar 16).

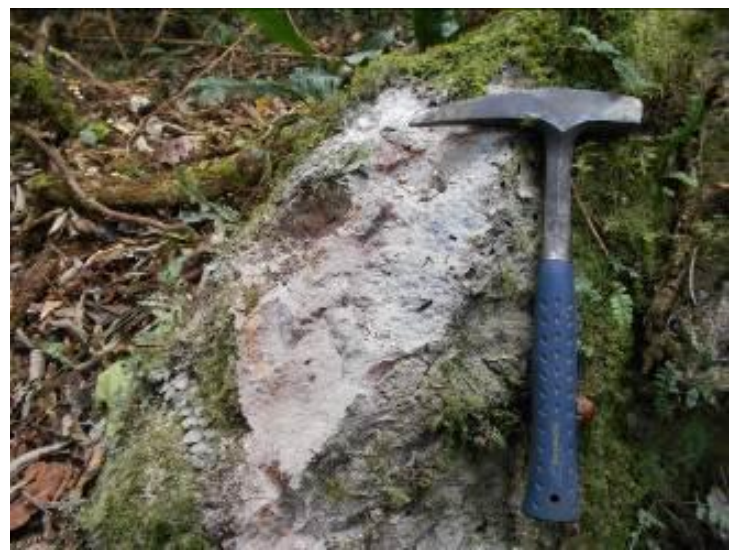

Gambar 16. Silica boulder sekitar lereng Bulu Lawekang

Gambaran atau pola sebaran alterasi dan mineralisasi daerah penyelidikan dapat dilihat pada Gambar 17 berikut.

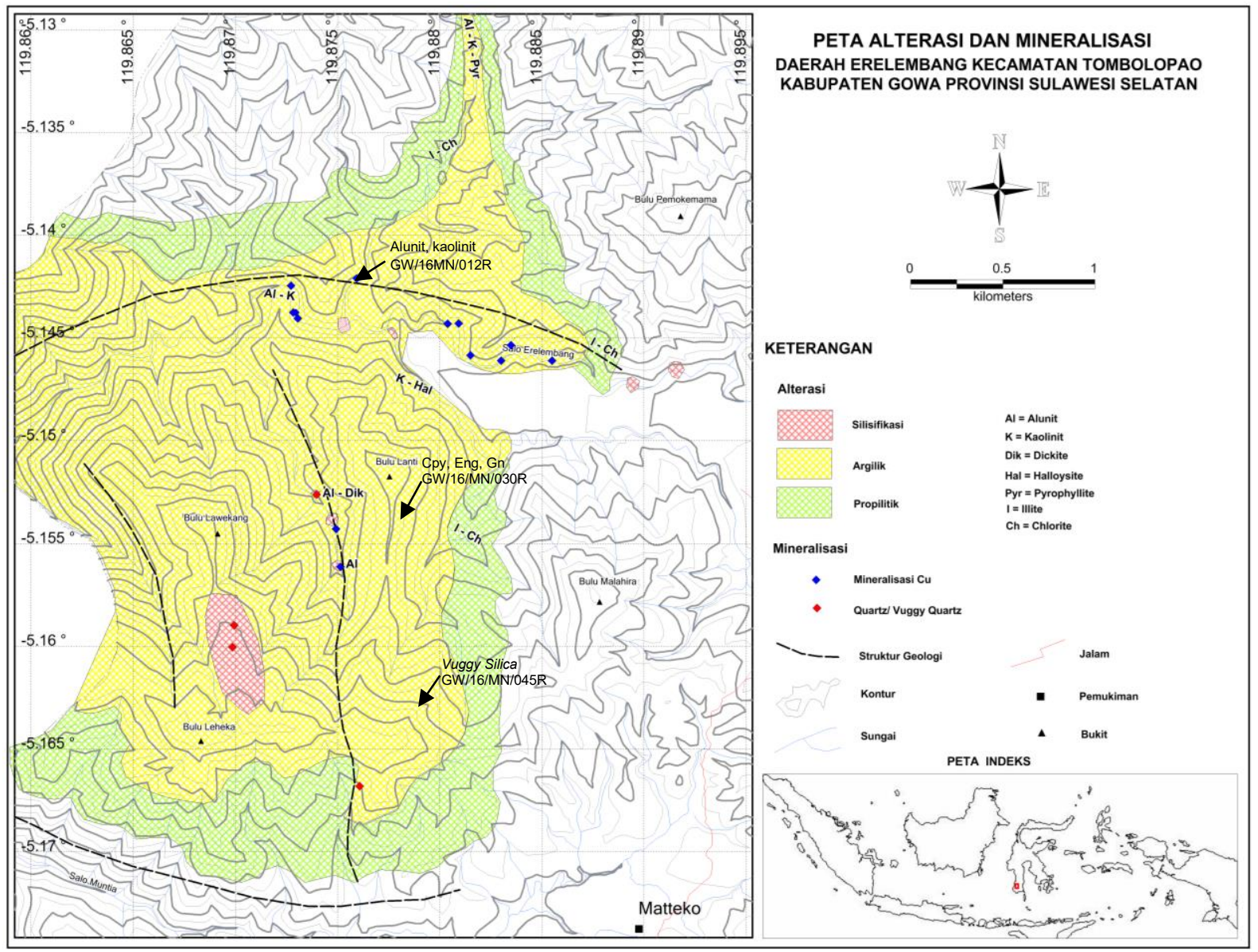

Gambar 17. Peta alterasi dan mineralisasi daerah penyelidikan 


\section{PEMBAHASAN}

Zona alterasi yang luas terutama zona argilik-argilik lanjut, merupakan bagian atau keseluruhan lithocap dari suatu zona cebakan mineralisasi yang signifikan dari hypogene silicic, advanced argillic dan argillic alteration, batuan yang bisa terbentuk di atas dan dalam kondisi dangkal kompleks hydro intrusive. Pembentukan batuan tersebut dapat sebagai pembawa mineralisasi sulfida tinggi. Beberapa overlay dan sebagian overprint cebakan porfiri, atau juga dapat berada di atas urat sulfida menengah, dengan kedalaman yang bisa mencapailebih dari $1 \mathrm{~km}$, bahkan mungkin melebihi $10 \mathrm{~km}$ dalam dimensi lateral (Silitoe,1995).

Kehadiran mineral ubahan yang bersifat asam seperti alunite, halloysite, jarosite, kaolinite, dickite, dan pyrophyllite dalam zona argilik-argilik lanjut yang luasnya lebih dari $2 \mathrm{~km}^{2}$ ini, menunjukkan zona batuan bersifat asam. Keterdapatan vuggy silica dalam zona batuan asam tersebut menunjukkan terjadinya proses pelarutan. Residu kuarsa vuggy merupakan produk dari pelarutan yang ekstrim (Stoffregen, 1987).

Mineral bijih yang terdapat di daerah penyelidikan, dari hasil analisis mineragrafi didominasi oleh pirit, diikuti tetrahidrit, kovelit, enargit, serta hydrous iron oxide, (dalam jumlah bervariasi) dan sedikit kalkopirit, malakit, tenantit, galena dan hematit. Sementara, berdasarkan hasil pengamatan langsung di lapangan, selain pirit yang dominan, sering dijumpai mineral sulfida tembaga, terutama malakit, sementara kalkopirit sangat jarang keterdapatannya. Keseluruhan mineral bijih tersebut umumnya tersebar dalam zona argilik-argilik lanjut. Berdasarkan dari kandungan mineral ubahan yang bersifat asam yang disebutkan diatas (alunite, halloysite, jarosite, kaolinite, dickite, dan pyrophyllite) dan dari kandungan mineral bijihnya serta keterdapatan vuggy silica, mencirikan endapan epitermal tipe sulfidasi tinggi. Hal ini juga didukung bahwa daerah penelitian ini merupakan zona alterasi yang luas sebagai lithocap. Cebakan sulfidasi tinggi merupakan seluruh atau sebagian dari lithocaps, yaitu zona alterasi argilik dan argilik lanjut cukup luas yang dihasilkan di antara lingkungan intrusi subvolcanic dan permukaan (Silitoe, 1995).

Meski zona alterasi luas dan berkembang dengan intensif, namun hasil analisis kimia mineral pada conto batuan dan tanah tidak menunjukkan kadar yang signifikan dan gambaran geokimia yang berarti. Keseluruhan dari 76 conto batuan tersebut, kadar maksimalnya; Au $35 \mathrm{ppb}$, Ag 2,9 ppm, Cu 136 ppm, Pb 317 ppm, dan Zn 220 ppm. Sementara dari 31 conto tanah, kadar maksimumnya Au 24 ppb, Ag 2,2 ppm, Cu 120 ppm, Pb 90 ppm, Zn 189 ppm, As 26 ppm, Sb 10 ppm, dan Hg 163 ppb. Rendahnya kadar mineral logam tersebut, diduga kuat karena lokasi pengambilan conto tersebut merupakan zona batuan bersifat asam yang sudah terlarutkan (Acid-leached zone). Batuan asam-larut (acid-leached) berasal dari uap panas dan silisifikasi muka air purba umumnya barren dari logam mulia dan logam dasar, yang tidak rentan terhadap transportasi yang mudah berubah, berlaku di bawah kondisi suhu rendah dan di lingkungan yang dipanaskan dengan uap. Namunmerkuri bersifat mobile dalam kondisi seperti itu dan dapat terkonsentrasi dalam batu asamlarut (acid-leached) sebagai cinnabar (Silitoe, 1999).

Hal menarik lainnya, adalah kemunculan anomali $\mathrm{Hg}$ yang terkonsentrasi di Pungungan Bulu Lawekang hingga percabangan dengan Bulu Laheka, yang relatif berbanding lurus dengan anomali $\mathrm{Au}$ dalam zona alterasi argilik-argilik lanjut dan silisifikasi. Namun kehadiran merkuri yang menunjukkan lingkungan endapan epitermal tipe sulfidasi tinggi tersebut diduga berada pada lingkungan yang dangkal.

Untuk memperkuat dugaan mengenai tipe dan lingkungan pengendapan mineralisasi di daerah penyelidikan, dapat dilihat dari 


\section{MAKALAH ILMIAH}

karakteristik endapannya dengan membandingkan zonasi tipe mineralisasi High Sulfidation (HS) menurut Silitoe (1999) pada gambar 18, dan Hedenquist et.al. (2000) pada Tabel 1.

Model mineralisasi Erelembang, jika merujuk kepada model mineralisasi berdasarkan Silitoe (1999) (skema rekonstruksi sistem HS dengan lingkungan porfiri sebagai dasar), termasuk ke dalam zona mineralisasi bagian atas, dari zona batuan yang bersifat asam (Acid-leached zone), seperti yang terlihat pada Gambar 19.

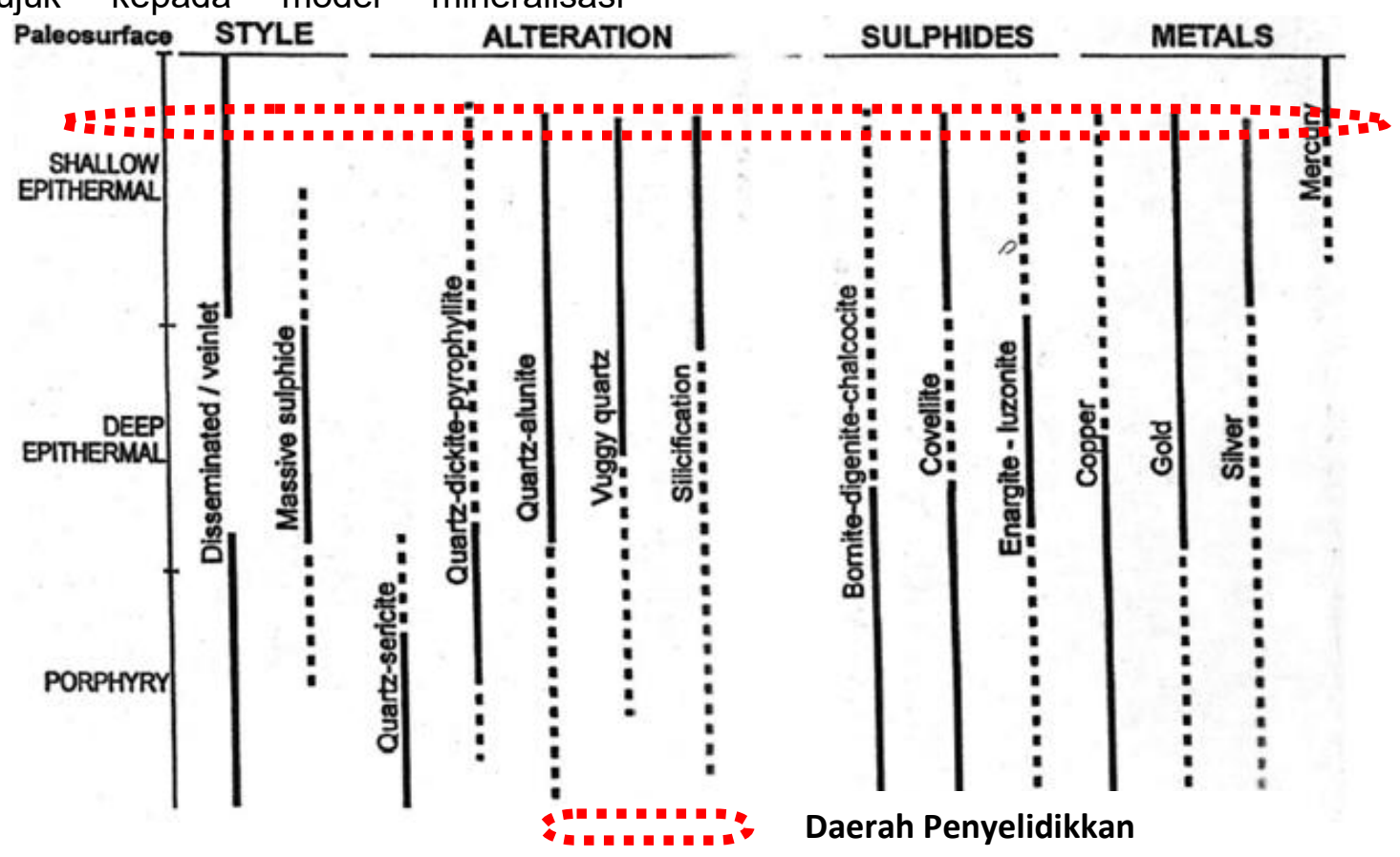

Gambar 18. Aspek utama zonasi vertikal tipe mineralisasi sistem HS, jenis, macam sulfida dan logam dalam sistem HS (Silitoe, 1999) dibandingkan dengan daerah penyelidikkan.

Tabel 1. Perbandingan karakteristik cebakan epitermal sulfidasi tinggi di daerah penelitian dengan model epitermal dari Hedenquist ,et.al, (2000).

\begin{tabular}{|c|c|c|c|c|}
\hline & \multicolumn{3}{|c|}{ Cebakan epitermal sulfidasi tinggi (hedenquist dkk, 2000) } & \multirow[t]{2}{*}{ Daerah Penelitian } \\
\hline & Dangkal & Menengah & Dalam & \\
\hline Kedalaman & $<500 \mathrm{~m}$ & $500 \mathrm{~m}$ s.d. $1000 \mathrm{~m}$ & $>1000 \mathrm{~m}$ & $<500 \mathrm{~m}$ \\
\hline Host rock & $\begin{array}{l}\text { Dome, piroklastik, } \\
\text { batuan sedimen }\end{array}$ & $\begin{array}{l}\text { Dome, diatrem, batuan } \\
\text { vulkanik }\end{array}$ & $\begin{array}{l}\text { Dome-diatrem, } \\
\text { porfiri, vulkanik, } \\
\text { batuan } \\
\text { volkanisklastik }\end{array}$ & Volkanik (andesit) \\
\hline $\begin{array}{l}\text { Bentuk } \\
\text { cebakan }\end{array}$ & $\begin{array}{l}\text { Disseminated, breksi, } \\
\text { veinlet }\end{array}$ & $\begin{array}{l}\text { Vein sulfida masif, } \\
\text { breksi, veinlet }\end{array}$ & $\begin{array}{l}\text { Disseminated, } \\
\text { veinlet, breksi }\end{array}$ & Disseminated \\
\hline Tekstur bijih & Vuggy kuarsa & $\begin{array}{l}\text { Sulfida masif, } \\
\text { vein/breksi }\end{array}$ & replacement & Vuggy kuarsa \\
\hline Alterasi & $\begin{array}{l}\text { Selisik (vuggy) kuarsa- } \\
\text { alunit }\end{array}$ & $\begin{array}{l}\text { Silisik (vuggy), kuarsa- } \\
\text { alunit, pirofilit-dickite- } \\
\text { seridit }\end{array}$ & $\begin{array}{l}\text { Pirofilit-serisit, } \\
\text { kuarsa-serisit }\end{array}$ & $\begin{array}{l}\text { Silisisik (vuggy), } \\
\text { alunite, halloysite, } \\
\text { jarosite, kaolinite, } \\
\text { dickite, dan } \\
\text { phirophyllite }\end{array}$ \\
\hline $\begin{array}{l}\text { Mineral } \\
\text { ganque }\end{array}$ & Alunit, barit, kaolinit & Anhidrit, kaolin, dickite & Serisit, pirofilit & $\begin{array}{l}\text { Alunit, kaolinit, } \\
\text { dickite, pirofilit }\end{array}$ \\
\hline $\begin{array}{l}\text { Mineral } \\
\text { sulfida }\end{array}$ & $\begin{array}{l}\text { Enargit/luzonit, kovelit, } \\
\text { pirit }\end{array}$ & $\begin{array}{l}\text { Enargit/luzonit, } \\
\text { kalkopirit, } \\
\text { tetrahedrit/tenantit, } \\
\text { sfalerit, kavelit, pirit }\end{array}$ & $\begin{array}{l}\text { Bornit, diagenit, } \\
\text { kalkosit, pirit }\end{array}$ & $\begin{array}{l}\text { Pirit, enargit, } \\
\text { kovelit, tetrahedrit, } \\
\text { malakit, kalkopirit, } \\
\text { tenantit, galena, } \\
\text { hematit }\end{array}$ \\
\hline
\end{tabular}




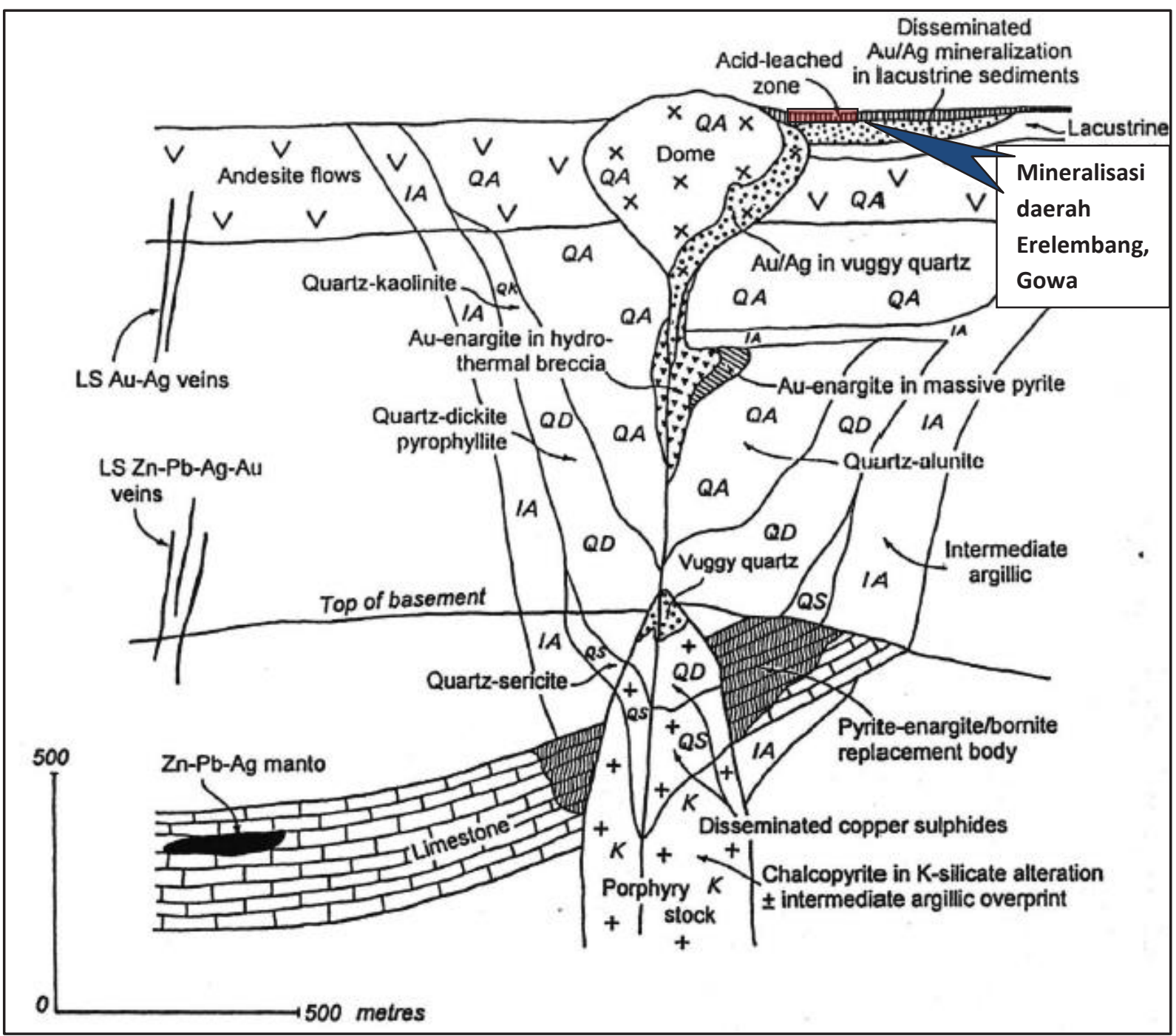

Gambar 19. Posisi mineralisasi spekulatif daerah Erelembang berdasarkan model mineralisasi Silitoe (1999)

\section{KESIMPULAN}

Batuan pembawa mineralisasi di daerah penyelidikan terjadi pada batuan vulkanik lava andesit.

Indikasi mineralisasi ditunjukkan dengan adanya zona alterasi yang luas berupa lithocap terdiri dari; zona silisifikasi (silika masif \& silika vuggy), zona argilik-argilik lanjut, dan zona propilit. Kehadiran mineral ubahan menunjukkan lingkungan asam yang tinggi seperti alunite, halloysite, jarosite, kaolinite, dickite, dan pyrophyllite dalam zona argilik-argilik lanjut. Keterdapatan silika vuggy dalam zona batuan asam tersebut menunjukkan terjadinya proses pelarutan.
Mineral bijih di daerah penyelidikan, didominasi oleh mineral pirit, dan diikuti adanya tetrahidrit, kovelit, enargit, serta hydrous iron oxide, dan sedikit kalkopirit, malakit, tenantit, galena dan hematit, yang pada umumnya tersebar (disseminated) dalam zona argilik-argilik lanjut.

Berdasarkan karakteristik dari mineral ubahan yang bersifat asam serta kandungan mineral bijihnya (enargit, tenantit, tetrahedrit, dan kovelit) dan keterdapatan silika vuggy, hal ini merupakan ciri dari endapan epitermal tipe sulfidasi tinggi. Konsentrasi anomali merkuri di Bulu Lawekang menguatkan dugaan bahwa lingkungan endapan epitermal sulfidasi tinggi tersebut, 


\section{MAKALAH ILMIAH}

terindentifikasi berada pada lingkungan mineralisasi di zona dangkal.

Dugaan kuat mineralisasi di wilayah ini diperkirakan masih jauh dari sumbernya, karena yang teramati masih merupakan zona bagian atas dari style mineralisasi sulfida tinggi.

\section{UCAPAN TERIMA KASIH}

Penulis mengucapkan terima kasih kepada Kepala Pusat Sumber Daya Mineral Batubara dan Panas Bumi, Kepala Bidang Mineral, Kepala Subbidang Mineral logam, serta semua pihak yang telah membantu dalam pembuatan tulisan ini.

\section{DAFTAR PUSTAKA}

Arribas, A., 1995. Epithermal High Sulfidation Mineralogical Ass. of Canada Short Course Vol.2.

Cooke DR, 2014, Characteristics, origins and significance for porphyry and epithermal exploration.

Hedenquist, J.W., 1996, Epithermal gold deposits: style, characteristics and exploration, Resources Geology Spec. Issue No1.

Hedenquist, J. W., Arribas, A., Jr., and Gonzalez-Urien, E., 2000, Exploration for epithermal gold deposits: Reviews in Economic Geology, v. 13.

Kadarusman, Ade., Maruyama, S., 2014. World's youngest blueschist belt from Leti Island in the non-volcanic Banda outer arc of Eastern Indonesia, Gondwana Research, Elsevier.
Monnier, C., Bellon, H., Girardeau, J., 1994. Datation 40K-40Ar de l'ophiolite de l'ile de Sulawesi, Indonesia.Paris, Academi desSciences, Comptes Rendue, V 319, ser, 249-356.

Parkinson, C.D., and Silver 1998..An outline of thr petrology, structure and age of the Pompangeo Schict Complex of Central Sulawesi, Indonesia. The Island Arc 7, 1-2, 231245.

Pirajno, Franco, 2016, Hydrothermal mineral system, Module Training 'Exploration and Development of Mineral Resources', KIGAM South Korea.

Silitoe, $\mathrm{RH}, \quad 1999$, Styles of High_Sulphidation Gold, Silver and Copper Mineralisation in Porphyry and Ephitermal Environments, Bali.

Stoffregen,. and Charles N., 1987, Woodhouseite and Swnbergite in Hydrotermal Ore deposits Product of apatite during advance argillic alteration, The Canadian Mineralogist.

Sukamto, Rab dan Sam Supriatna, 1982, Peta Geologi Lembar Ujung Pandang, Benteng, dan Sinjai, Sulawesi, Skala $1: 250.000$. PPPG, Bandung.

Van Leeuwen, T.M \& Pieters , P.E., 2011, Mineral Deposit of Sulawesi, Manado.

Zulkifli M.D., dan Moe'tamar., 2002, Inventarisasi dan Evaluasi Mineral logam di Kabupaten Takalar dan Kabupaten Gowa, Propinsi Sulawesi Selatan, Direktorat Inventarisasi Sumber Daya Mineral, Bandung.

\begin{tabular}{|ll|}
\hline Diterima & $:$ 28 Oktober 2019 \\
Direvisi & $:$ 5 November 2019 \\
Disetujui & $:$ 30 November 2019
\end{tabular}

